\title{
EFEKTIVITAS PEMBINAAN DAN PENGAWASAN KLINIK PRATAMA RAWAT INAP TERKAIT TENAGA MEDIS BERDASARKAN PERATURAN MENTERI KESEHATAN RI NOMOR 9 TAHUN 2014 DI KABUPATEN CILACAP Novita Kukilowati \\ (Dinas Kesehatan Kabupaten Cilacap)
}

\begin{abstract}
One of the health facilities namely clinic, in Act No. 36 of 2009 about health issues and set up, refer to the clinic with a regulation of the Minister of health no. 92014 about clinics, which mentions that the clinic is a health care facility which hosts individual health services that provide basic medical services and/or the including specialised.

Specification of the research is descriptive, with the purpose of: 1 to analyze the effectiveness of supervision and Coaching Clinic Pratama related Inpatient medical personnel based on the regulation of the Minister of health RI No. 92014 in Cilacap Regency. 2 to analyze the factors that impede any coaching and supervision the clinic Pratama Hospitalization in Cilacap Regency.

The effectiveness of coaching and supervision of medical personnel against operational clinics based on the regulation of the Minister of health no. 92014 in Cilacap Regency that supervision, coaching and medical clinic at tenga pratama which hosts when rawap, Cilacap Regency Health Office carried out in the form of coaching in the form of guidance contained in the News Events Outreach conducted three (3) months and overall evaluation good the facilities that support the, medical equipment, a form of basic services as well as S.O. P clinic pratama.
\end{abstract}

\begin{abstract}
Abstrak
Salah satu fasilitas kesehatan yaitu klinik, dalam UU No. 36 Tahun 2009 tentang Kesehatan, merujuk dan mengatur masalah klinik dengan adanya Peraturan Menteri Kesehatan Nomor 9 Tahun 2014 tentang Klinik, yang menyebutkan bahwa klinik adalah fasilitas pelayanan kesehatan yang menyelenggarakan pelayanan kesehatan perorangan yang menyediakan pelayanan medis dasar dan/atau spesialistik.

Spesifikasi penelitian ini adalah deskriptif, dengan tujuan: 1 untuk menganalisis efektivitas pembinaan dan pengawasan Klinik Pratama Rawat Inap terkait Tenaga Medis berdasarkan Peraturan Menteri Kesehatan RI Nomor 9 Tahun 2014 di Kabupaten Cilacap. 2 Untuk menganalisis faktor-faktor apa saja yang menghambat pembinaan dan pengawasan Klinik Pratama Rawat Inap di Kabupaten Cilacap.

Efektivitas pembinaan dan pengawasan tenaga medis terhadap operasional klinik berdasarkan Peraturan Menteri Kesehatan Nomor 9 Tahun 2014 di Kabupaten Cilacap bahwa, pembinaan dan pengawasan tenga medis pada klinik pratama yang menyelenggarakan rawap inap, dilakukan dinas kesehatan Kabupaten Cilacap dalam bentuk pembinaan berupa penyuluhan yang tertuang dalam Berita Acara Penyuluhan yang dilakukan 3 (tiga) bulan sekali serta evaluasi secara menyeluruh baik fasilitas yang menunjang, peralatan medis, bentuk pelayanan dasar serta S.O.P klinik pratama.
\end{abstract}

\section{PENDAHULUAN}

Keberadaan institusi kesehatan yang memberikan pelayanan kesehatan saat ini yang berkembang tidak hanya rumah sakit, namun juga klinik. Klinik sebagai salah satu bentuk fasilitas pelayanan kesehatan dibutuh kan untuk terselenggaranya pelayanan kesehatan yang mudah diakses, terjangkau dan bermutu dalam rangka meningkatkan derajat kesehatan masyarakat.

Salah satu fasilitas kesehatan yaitu klinik, dalam Undang-undang Nomor 36 Tahun 2009 
tentang Kesehatan, merujuk dan mengatur masalah klinik dengan adanya Peraturan Menteri Kesehatan Nomor 9 Tahun 2014 tentang Klinik, yang menyebutkan bahwa klinik adalah fasilitas pelayanan kesehatan yang menyelenggarakan pelayanan kesehatan perorangan yang menyediakan pelayan an medis dasar dan/atau spesialistik.

Pelayanan kesehatan di dalam klinik pada dasarnya sama seperti rumah sakit dan dokter sebagai pelayan kesehatan memberikan pelayanan kesehatan kepada pasien sebagai penerima pelayanan kesehatan, hal tersebut dilakukan oleh pasien dengan cara mendatangi klinik untuk melakukan upaya kesehatan, selanjutnya pasien bertemu dengan dokter untuk membicarakan keluhan atau sakit yang di derita kemudian setelah mendengar keluhan pasien, dokter meminta izin untuk memeriksa keluhan pasien, setelah memeriksa keluhan atau sakit yang diderita pasien barulah dokter menyimpul- kan atau mendiagnosa sakit pasien dengan keilmuan kedokteran yang dimilikinya dan yang terakhir memberikan resep obat untuk membantu pasien dalam proses penyembuhan penyakit. $^{1}$

Pemerintah telah mengeluarkan Peraturan Menteri Kesehatan Nomor 9 Tahun 2014 tentang Klinik. Pasal 1 angaka 1 Peraturan Menteri Kesehatan Nomor 9 Tahun 2014 tentang Klinik, menyatakan bahwa Klinik adalah fasilitas pelayanan kesehatan yang menyelenggarakan pelayanan kesehatan perorangan yang menyediakan pelayanan

Sony Wijaya, Keberadaan Klinik dan Pelayanan Kesehatan oleh Dokter, http://www.klinikonline.blogspot.com, diakses pada tanggal 28 September 2015, hal 1. medis dasar dan/atau spesialistik. Peraturan Menteri Kesehatan Nomor 9 Tahun 2014 tentang Klinik, Pasal 2 menentukan mengenai jenis klinik, yaitu klinik pratama dan klinik utama dan yang membedakannya adalah jika klinik pratama hanya menyelenggarakan pelayanan medik dasar, sedangkan klinik utama menyelenggarakan pelayanan spesialistik atau pelayanan medik dasar dan spesialistik. Dengan begitu setiap klinik terdapat batasan atau terdapat kewenangan untuk memeriksa dan tidak setiap klinik berwenang untuk memeriksa penyakit tertentu. $^{2}$ Klinik dapat dimiliki oleh Pemerintah, Pemerintah Daerah, atau masyarakat. Klinik yang dimiliki pemerintah, pemerintah daerah atau masyarakat harus didirikan sesuai dengan ketentuan peraturan perundang-undangan. Sedangkan klinik yang dimiliki oleh masyarakat yang menyelenggarakan rawat jalan dapat didirikan oleh perorangan atau badan usaha. Klinik yang dimiliki oleh masyarakat yang menyelenggarakan rawat inap harus didirikan oleh badan hukum. ${ }^{3}$

Peraturan Menteri Nomor 9 Tahun 2014 tentang Klinik, terkait dengan tenaga medis pelayanan klinik kesehatan sebagaimana diatur dalam ketentuan Pasal 9 yang menyatakan bahwa:

(1) Penanggung jawab teknis Klinik harus seorang tenaga medis;

(2) Penanggung jawab teknis Klinik sebagaimana dimaksud pada ayat (1) harus memiliki Surat Izin Praktik (SIP) di Klinik tersebut, dan dapat merangkap sebagai pemberi pelayanan.

Ibid., hal 2.

Pasal 4 Permenkes Nomor 9 Tahun 2014 tentang Klinik. 
Pasal 12 :

(1) Tenaga medis pada Klinik pratama yang memberikan pelayanan kedokteran paling sedikit terdiri dari 2 (dua) orang dokter dan/atau dokter gigi sebagai pemberi pelayanan;

(2) Tenaga medis pada Klinik utama yang memberikan pelayanan kedokteran paling sedikit terdiri dari 1 (satu) orang dokter spesialis dan 1 (satu) orang dokter sebagai pemberi pelayanan;

(3) Tenaga medis pada Klinik utama yang memberikan pelayanan kedokteran gigi paling sedikit terdiri dari 1 (satu) orang dokter gigi spesialis dan 1 (satu) orang dokter gigi sebagai pemberi pelayanan.

Klinik pratama rawat Inap di Kabupaten Cilacap berkembang cukup pesat. Pada tahun 2012 telah dikeluarkan izin operasional klinik pratama rawat inap sebanyak 23 (dua puluh tiga) klinik. Berkembangnya klinik tersebut terkait dengan upaya peningkatan pelayanan kesehatan kepada masyarakat. ${ }^{4}$ Data tahun 2014 didapatkan sebanyak 40 (empat puluh ) Klinik Pratama Rawat Inap, dan sampai dengan akhir bulan Desember 2015 tercatat ada 49 (empat puluh sembilan) Klinik Pratama Rawat Inap yang berizin dan beroperasional di Kabupaten Cilacap. ${ }^{5}$

Gambaran umum fasilitas pelayanan kesehatan Dinas Kesehatan Kabupaten Cilacap berorientasi pada ketersediaan sarana prasarana (sarpras) yang mendukung kelancaran sistem pelayanan kesehatan di

Dinas Kesehatan Kabupaten Cilacap Tahun 2012 2014 (Sebagai Data Awal Penelitian).

5 Ibid.
Dinas Kesehatan Kabupaten Cilacap dan jaringannya yang meliputi: ${ }^{6}$

\section{Sarana fasilitas kesehatan pemerintah maupun swasta}

Tabel I

Fasilitas Fisik Pelayanan Kesehatan Kabupaten Cilacap

\begin{tabular}{|c|c|c|c|}
\hline No & $\begin{array}{c}\text { Jenis } \\
\text { Fasilitas }\end{array}$ & Jumlah & Kepemilikan \\
\hline 1. & $\begin{array}{l}\text { Rumah } \\
\text { Sakit }\end{array}$ & 2 & Pemda \\
\hline 2. & $\begin{array}{l}\text { Rumah } \\
\text { Sakit }\end{array}$ & 8 & Swasta \\
\hline 3. & $\begin{array}{l}\text { Klinik } \\
\text { Utama }\end{array}$ & 3 & Swasta \\
\hline 4. & $\begin{array}{l}\text { Klinik } \\
\text { Pratama } \\
\text { Rawat } \\
\text { Jalan }\end{array}$ & 15 & Swasta \\
\hline 5. & $\begin{array}{l}\text { Klinik } \\
\text { Pratama } \\
\text { Rawat } \\
\text { Inap }\end{array}$ & 49 & Swasta \\
\hline 6. & $\begin{array}{l}\text { Klinik } \\
\text { Kecantik } \\
\text { an }\end{array}$ & 6 & Swasta \\
\hline 7. & Apotik & 126 & $\begin{array}{l}\text { Swasta } \\
\text { 123/Pemda } \\
3\end{array}$ \\
\hline 8. & Optik & 18 & Swasta \\
\hline 9. & $\begin{array}{l}\text { Toko } \\
\text { Obat }\end{array}$ & 27 & Swasta \\
\hline 10. & $\begin{array}{l}\text { Puskes } \\
\text { mas } \\
\text { Rawat } \\
\text { Jalan }\end{array}$ & 24 & \\
\hline 11. & $\begin{array}{l}\text { Puskes } \\
\text { mas } \\
\text { Rawat } \\
\text { Inap }\end{array}$ & 14 & \\
\hline 12. & $\begin{array}{l}\text { Puskes } \\
\text { mas } \\
\text { Pemban } \\
\text { tu }\end{array}$ & 79 & \\
\hline 13. & $\begin{array}{l}\text { Poliklini } \\
\text { k } \\
\text { Kesehat } \\
\text { an Desa }\end{array}$ & 212 & \\
\hline
\end{tabular}

Data diperoleh Dinas Kesehatan Kabupaten Cilacap Tahun 2015. 


\section{Data Sumber Daya}

\section{Tabel II}

Data tenaga Kesehatan Kabupaten

Cilacap sampai dengan bulan

Desember 2015

\begin{tabular}{|l|l|c|}
\hline No & \multicolumn{1}{|c|}{ Tenaga } & $\begin{array}{c}\text { Jumlah } \\
\text { (orang) }\end{array}$ \\
\hline 1. & Dokter umum & 249 \\
\hline 2. & Dokter gigi & 45 \\
\hline 3. & Dokter spesialis & 57 \\
\hline 4. & Bidan & 690 \\
\hline 5. & Perawat & 430 \\
\hline 6. & Apoteker & 181 \\
\hline & Jumlah & 1652 \\
\hline
\end{tabular}

Dari data di atas, bahwa Dinas

Kesehatan Kabupaten Cilacap telah melakukan pembinaan dan pengawasan yaitu berupa pendataan jumlah terhadap operasional klinik serta jumlah tenaga medis baik milik Pemerintah Daerah atau pun milik swasta. Dalam penyelenggaraan usaha klinik Pratama Rawat Inap, para pesertanya akan mengadakan kerja sama dan dengan adanya kerja sama tersebut akan melahirkan konsekuensi yuridis, terutama mengenai tanggung jawab usaha klinik Pratama Rawat Inap tersebut. Dengan terbitnya Peraturan Menteri Kesehatan Nomor 9 Tahun 2014 tentang Klinik, dalam perkembangannya terkait dengan peningkatan upaya pelayanan kesehatan kepada masyarakat. Namun, kenyataannya di lapangan khususnya Klinik Pratama rawat inap di Kabupaten Cilacap belum efektif. Seringkali klinik yang sudah mendapatkan izin operasional dalam perjalanannya tidak memenuhi standar operasional klinik lagi karena tenaga medis yang ada di dalamnya berkurang jumlahnya, sehingga ada yang salah, baik dalam manajemen pelayanan maupun implementasinya yang mengakibatkan upaya peningkatan pelayanan kesehatan kepada masyarakat tidak optimal, hal ini dikarenakan tenaga medis di Kabupaten Cilacap terbatas jumlahnya. ${ }^{7}$

\section{RUMUSAN MASALAH}

Berdasarkan uraian di atas, dapat dirumuskan permasalahan sebagai berikut: pertama, bagaimanakah efektivitas pembinaan dan pengawasan Klinik Pratama Rawat Inap terkait Tenaga Medis berdasarkan Peraturan Menteri Kesehatan RI Nomor 9 Tahun 2014 di Kabupaten Cilacap. Kedua, Faktor-faktor apa saja yang menghambat pembinaan dan pengawasan Klinik Pratama Rawat Inap di Kabupaten Cilacap .

\section{METODE PENELITIAN}

Metode penelitian yang digunakan adalah Yuridis Sosiologis, yaitu pendekatan yang menekankan pada pencarian fakta-fakta, karena mengkontruksi hukum sebagai refleksi kehidupan masyarakat itu sendiri di dalam praktik konsekuensinya adalah apabila tahap pengumpulan data sudah dikerjakan yang dikumpulkan bukan hanya yang disebut dalam hukum tertulis saja akan tetapi diadakan observasi terhadap tingkah laku yang benarbenar terjadi. ${ }^{8}$

Spesifikasi penelitian ini adalah deskriptif, yaitu suatu penelitian yang menggambarkan keadaan obyek yang akan diteliti. ${ }^{9}$ Sumber Data: data Primer dan data Sekunder. Narasumber

Dinas Kesehatan Kabupaten Cilacap.

Ronny Hanintijo Sumitro, Metodologi Penelitian Hukum, Ghalia Indonesia, Jakarta, 1988, hal. 35.

9 Abdul Kadir Muhammad, Metode Penelitian Hukum, PT. Raja Grafindo, Jakarta, 2004, hal 16. 
ditentukan dengan cara atau metode Purposive Sampling.

\section{PEMBAHASAN}

Efektivitas pembinaan dan pengawasan tenaga medis terhadap operasional klinik berdasarkan Peraturan Menteri Kesehatan Nomor 9 Tahun 2014 di Kabupaten Cilacap

Menurut dr. Marwoto, M.Si (Kepala Dinas Kesehatan Kabupaten Cilacap) memberikan pendapatnya bahwa masalah efektivitas pembinaan dan pengawasan tenaga medis terhadap operasional klinik berdasarkan Peraturan Menteri Kesehatan Nomor 9 Tahun 2014 di Kabupaten Cilacap, pembinaan dan pengawasan yang sudah dilakukan oleh dinas kesehatan dilakukan secara berkala. Pembinaan dimaksudkan agar Klinik Pratama Rawat Inap dalam penyelenggaraan pelayanan kesehatan sesuai ketentuan peraturan perundangundangan dan pengawasan dilakukan terkait dengan S.O.P yang ditetapkan sehingga tak terjadi masalah hukum dikemudian hari. ${ }^{10}$

$\begin{array}{lll}\text { Selanjutnya narasumber memberikan } & \text { mengenai faktor-faktor }\end{array}$
penghambat pelaksanaan Peraturan Menteri Kesehatan Nomor 9 Tahun 2014 tentang Klinik di Kabupaten Cilacap, sebagai berikut: Pemerintah daerah dalam hal ini dinas kesehatan Kabupaten Cilacap, telah melakukan pembinaan dan pengawasan (binwas) terhadap klinik-klinik kesehatan yang di kabupaten Cilacap khususnya klinik pratama yang memberlakukan rawap inap terhadap pasien, pembinaan dan pengawasan dilakukan berupa

\footnotetext{
${ }^{10}$ Hasil wawancara dengan dr. Marwoto, M.Si (Kepala Dinas Kesehatan Kabupaten Cilacap), pada tanggal 22 Februari 2016.
}

sosialisasi Permenkes tersebut, dan tentunya dinas kesehatan mempunyai kewenangan untuk menegur apabila dalam pengawasan terjadi pelanggaran dalam SOP-nya. ${ }^{11}$

Sedangkan menurut Slamet Budiarto, S.E., M.M (Kepala Bidang Pelayanan Kesehatan Dinas Kesehatan Kabupaten Cilacap) dalam wawancaranya memberikan pendapatnya, bahwa ada Klinik yang masa izin operasional sudah habis, dan dinas kesehatan Kabupaten Cilacap masih memberikan kesempatan supaya untuk mengurus perizinan tersebut sesuai dengan Peraturan Menteri Kesehatan Nomor 9 Tahun 2014 tentang Klinik, sehingga legalitas klinik tersebut berdasarkan ketentuan peraturan perundang-undangan yang berlaku. ${ }^{12}$

Lebih lanjut, narasumber Slamet Budiarto, S.E., M.M (Kepala Bidang Pelayanan Kesehatan Dinas Kesehatan Kabupaten Cilacap), memberikan argumennya, sebagai berikut: Persyaratan perizinan dalam pendirian klinik pratama yang diajukan masyarakat sebenarnya sangatlah mudah dan biaya yang terjangkau dalam perizinannya, para pemohon tinggal melengkapi persyaratan berdasarkan ketentuan peraturan perundang-undangan. Pemerintah daerah dalam hal ini dinas kesehatan Kabupaten Cilacap, mempunyai wewenang untuk meloloskan atau pun menolak pendirian perizinan khususnya klinik pratama. ${ }^{13}$

Narasumber memberikan data mengenai jumlah klinik pratama, yang ada di Kabupaten

\footnotetext{
${ }^{11}$ Hasil wawancara dengan dr. Marwoto, M.Si (Kepala Dinas Kesehatan Kabupaten Cilacap), pada tanggal 22 Februari 2016.

12 Hasil wawancara dengan Slamet Budiarto, S.E., M.M. (Kepala Bidang Pelayanan Kesehatan Dinas Kesehatan Kabupaten Cilacap), pada tanggal 22 Februari 2016.

13 Hasil wawancara dengan Slamet Budiarto, S.E., M.M. (Kepala Bidang Pelayanan Kesehatan Dinas Kesehatan Kabupaten Cilacap), pada tanggal 22 Februari 2016.
} 
Cilacap, baik itu Klinik Pratama Rawat Jalan maupun Klinik Pratama Rawat Inap. Untuk Klinik Pratama Rawat Jalan yang ada di Kabupaten Cilacap berjumlah 15 Unit, dan Klinik Pratama Rawat Inap yang ada di Kabupaten Cilacap berjumlah 49 Unit yang seluruhnya dimiliki oleh pihak swasta. Dengan jumlah klinik yang begitu banyak di Kabupaten Cilacap, maka pemerintah daerah dalam hal ini dinas kesehatan telah melakukan pengawasan yang ketat terkait dengan perizinan terhadap operasional klinikklinik pratama tersebut dan juga pembinaan SDM tenaga medis yang dilakukan 3 (tiga) bulan sekali. ${ }^{14}$

Pendapat Pelaksana program Bidang Pelayanan Kesehatan Dinas Kesehatan Kabupaten Cilacap, Mila Wijayanti, S.Kep Ness, M.MR, menguraikan pendapatnya mengenai Peraturan Menteri Nomor 9 Tahun 2014 tentang Klinik, merupakan dasar hukum dalam pelaksanaan klinik di daerah. Terkait dengan pembinaan dan pengawasan Klinik Pratama Rawat Inap terkait Tenaga Medis sudah berjalan, namun ada tenaga medis yang terikat kontrak kerja dengan klinik tersebut di tengah jalan tenaga medis tersebut pindah kerja atau model kerja fre line terutama dokter atau dokter gigi, sehingga menimbulkan persoalan dalam penyelenggaraan klinik tersebut. ${ }^{15}$

Seterusnya narasumber Mila Wijayanti, S.Kep Ness, M.MR, memberikan pendapatnya, pembinaan dan pengawasan tenaga medis khususnya di klinik pratama, sebagai berikut :

14 Hasil wawancara dengan Slamet Budiarto, S.E., M.M. (Kepala Bidang Pelayanan Kesehatan Dinas Kesehatan Kabupaten Cilacap), pada tanggal 22 Februari 2016.

15 Hasil wawancara dengan Mila Wijayanti, S.Kep Ness, M.MR (Pelaksana program Bidang Pelayanan Kesehatan Dinas Kesehatan Kabupaten Cilacap), pada tanggal 23 Februari 2016.
SOP pembinaan dan pengawasan di klinik pratama rawat inap terkait tenaga medis di Kabupaten Cilacap, sebenarnya sudah berjalan dengan standar pelayanan kesehatan dan peraturan perundang-undangan khususnya Peraturan Menteri Nomor 9 Tahun 2014 tentang Klinik, pembinaan dilakukan berupa penyuluhan 3 (tiga) bulan sekali terutama mengenai S.O.P serta sosialisasi peraturan perundang-undangan yang terkait oleh dinas kesehatan Kabupaten Cilacap. Sedangkan pengawasan terhadap klinik pratama yang menyelenggarakan rawap inap di Kabupaten Cilacap berupa pendataan secara berkala baik berupa terhadap tenaga medis (dokter), perawat dan sarana prasarana (sanpras) di klinik tersebut. ${ }^{16}$

Staff Dinas Kesehatan Kabupaten Cilacap Bagian Farmasi, Erna Kartika Rahaju, S. Farm.Apt., salah satu narasumber yang telah diwawancarai memberikan pendapatnya mengenai pembinaan dan pengawasan di klinik pratama rawat inap terkait tenaga medis di Kabupaten Cilacap, pembinaan dimaksudkan agar para penyelenggara pelayanan kesehatan di klinik pratama meningkatkan pengetahuan Iptek khususnya dokter dan dokter gigi sebagai penanggungjawab operasional klinik tersebut serta pengawasan dilakukan oleh dinas kesehatan Kabupaten Cilacap agar tak terjadi permasalahan hukum, sehingga hak-hak pasien tak terabaikan. ${ }^{17}$

Selanjutnya narasumber Erna Kartika Rahaju, S. Farm., Apt memberikan pendapatnya

\footnotetext{
${ }^{16}$ Hasil wawancara dengan Mila Wijayanti, S.Kep Ness, M.MR (Pelaksana program Bidang Pelayanan Kesehatan Dinas Kesehatan Kabupaten Cilacap), pada tanggal 23 Februari 2016.

17 Hasil wawancara dengan Erna Kartika Rahaju, S. Farm., Apt. (Staff Dinas Kesehatan Kabupaten Cilacap Bagian Farmasi), pada tanggal 24 Februari 2016.
} 
mengenai efektivitas Peraturan Menteri Nomor 9 Tahun 2014 tentang Klinik, sebagai berikut : dengan terbitnya Peraturan Menteri Kesehatan RI Nomor 9 Tahun 2014 tentang Klinik, efektif atau tidaknya Permenkes tersebut dapat dilihat kesiapan klinik keseluruhan baik tenaga medis, tenaga perawat dan fasilitas klinik serta sosialisasi kepada masyarakat. ${ }^{18}$

Penanggungjawab Klinik Aisyah Kabupaten Cilacap yaitu dokter Siti Solihah, M.MR berpendapat bahwa merujuk dengan adanya Peraturan Menteri Kesehatan Nomor 9 Tahun 2014 tentang Klinik, menyebutkan bahwa klinik adalah fasilitas pelayanan kesehatan yang menyelenggarakan pelayanan kesehatan perorangan yang menyediakan pelayanan medis dasar, sehingga pelaksanaan medis di klinik pratama di Kabupaten Cilacap telah sesuai dengan ketentuan Permenkes tersebut, namun ada juga klinik pratama yang belum memiliki peralatan medis yang memadai. ${ }^{19}$

Dokter Siti Solihah, M.MR., narasumber memberikan pendapatnya terkait dengan operasional klinik pratama, yang menyelenggarakan rawap inap, bahwa dalam hal pelayanan kesehatan di dalam klinik pratama pada dasarnya sama seperti rumah sakit dimana dokter sebagai pelayan kesehatan memberikan pelayanan kesehatan kepada pasien sebagai penerima pelayanan kesehatan, hal tersebut dilakukan oleh pasien dengan cara mendatangi klinik untuk melakukan upaya kesehatan, selanjutnya pasien bertemu dengan

\footnotetext{
${ }^{18}$ Hasil wawancara dengan Erna Kartika Rahaju, S. Farm. Apt. (Staff Dinas Kesehatan Kabupaten Cilacap Bagian Farmasi), pada tanggal 24 Februari 2016.

19 Hasil wawancara dengan dokter Siti Solihah, M.MR (Penanggungjawab Klinik Aisyah Kabupaten Cilacap), pada tanggal 25 Februari 2016.
}

dokter untuk membicarakan keluhan atau sakit yang di derita kemudian setelah mendengar keluhan pasien, dokter meminta izin untuk memeriksa keluhan pasien, setelah memeriksa keluhan atau sakit yang di derita pasien barulah dokter menyimpulkan atau mendiagnosa penyakit pasien yang sudah akut, maka dengan keilmuan kedokteran yang dimilikinya dan yang terakhir memberikan rekomendasi supaya diopname. Adanya Peraturan Menteri Kesehatan Nomor 9 Tahun 2014 tentang Klinik, sehingga pelaksanaan Permenkes tersebut dapat berjalan dengan baik dan juga sebagai dasar hukum keberadaan klinik di Kabupaten Cilacap. $^{20}$

Penanggungjawab Klinik Gelis Bergas Kabupaten Cilacap yaitu dokter Lini Nuraeni, menguraikan pendapatnya tentang tenaga medis di klinik pratama, bahwa tenaga kesehatan adalah setiap orang yang mengabdikan diri dalam bidang kesehatan serta memiliki pengetahuan dan/atau keterampilan melalui pendidikan di bidang kesehatan yang untuk jenis tertentu memerlukan kewenangan untuk melakukan upaya kesehatan. Sebenarnya terkait dengan tenaga medis pada pelayanan dasar kesehatan di klinik pratama yang ada di Kabupaten Cilacap, sudah memenuhi kriteria baik berupa kompetensi, cara menyimpulkan penyakit pasien dan tentunya S.O.P yang telah ditetapkan oleh pemerintah daerah khususnya dinas kesehatan, tergantung dari dinas kesehatan tinggal mengevaluasi dan

\footnotetext{
${ }^{20}$ Hasil wawancara dengan dokter Siti Solihah, M.MR (Penanggungjawab Klinik Aisyah Kabupaten Cilacap), pada tanggal 25 Februari 2016.
} 
memberikan pembinaan yang berkala terhadap para tenaga medis diklinik pratama. ${ }^{21}$

Salah satu perawat di Klinik Pratama di Kabupaten Cilacap, Khalifah Agus Prihatinah, AMK., mengungkapkan pendapatnya mengenai Peraturan Menteri Kesehatan Nomor 9 Tahun 2014 tentang Klinik, juga mengatur tentang klinik yang menyelenggarakan pelayanan kesehatan 24 (dua puluh empat) jam harus menyediakan dokter serta tenaga kesehatan (perawat) sesuai kebutuhan pelayanan dan setiap saat berada di tempat. Keberadaan dokter dalam klinik pratama yang dibantu 2 (dua) orang perawat atau pun lebih mempunyai peran masing-masing yang bertujuan untuk penyembuhan penyakit pasien. $^{22}$

Bakti Afriatun, AMK (Salah satu perawat di Klinik Pratama di Kabupaten Cilacap) memberikan pendapatnya bahwa kesehatan adalah faktor yang sangat penting bagi masyarakat, sehingga masyarakat lebih cenderung berobat ke klinik pratama yang biayanya terjangkau dan jarak tempuh yang dekat, karena klinik kesehatan di setiap kecamatan ada terutama yang berstatus swasta.

Terkait Peraturan Menteri Kesehatan Nomor 9 Tahun 2014 tentang Klinik sebagai pedoman terhadap klinik dalam memberikan pelayanan kesehatan kepada masyarakat. ${ }^{23}$

Pelayanan kesehatan adalah setiap upaya yang diselenggarakan sendiri atau bersama-sama dalam suatu organisasi untuk

21 Hasil wawancara dengan dokter Lini Nuraeni (Salah satu dokter di Klinik Pratama di Kabupaten Cilacap), pada tanggal 25 Februari 2016.

22 Hasil wawancara dengan Khalifah Agus Prihatinah, AMK (Salah satu perawat di Klinik Pratama di Kabupaten Cilacap), pada tanggal 26 Februari 2016.

23 Hasil wawancara dengan Bakti Afriatun, AMK (Salah satu perawat di Klinik Pratama di Kabupaten Cilacap), pada tanggal 26 Februari 2016. memelihara dan meningkatkan kesehatan, mencegah dan menyembuhkan penyakit serta memulihkan kesehatan perorangan, keluarga, kelompok dan ataupun masyarakat. Dalam hal ini, dapat dilakukan dengan pemberian penyuluhan kesehatan tentang bagaimana cara memelihara dan meningkatkan kesehatan, mencegah dan menyembuhkan penyakit serta memulihkan kesehatan perseorangan, keluarga, kelompok dan ataupun masyarakat yang meliputi pelayanan preventif (pencegahan) dan promotif (peningkatan kesehatan) dengan sasaran masyarakat. ${ }^{24}$

Undang-undang Nomor 36 Tahun 2009 tentang Kesehatan maupun Undang-undang Nomor 44 Tahun 2009 tentang Rumah Sakit, tidak ditemukan arti dari istilah "pelayanan kesehatan". Kedua Undang-undang tersebut langsung mencantumkan berbagai jenis "pelayanan kesehatan", antara lain : pelayanan kesehatan promotif, preventif, kuratif , rehabilitatif dan tradisional ${ }^{25}$ yang kesemuanya dikelompokkan dengan istilah lain yaitu "Pelayanan Kesehatan Paripurna". Lebih lanjut Pasal 30 Undang-undang Nomor 36 Tahun 2009 tentang Kesehatan mengemukakan istilah-istilah lain yang dikelompokkan ke dalam "fasilitas pelayanan kesehatan", yaitu : Pelayanan Kesehatan Perorangan, Pelayanan Kesehatan Masyarakat, lalu Pelayanan Kesehatan Tingkat Pertama, Kedua dan Ketiga. Akan tetapi terdapat istilah lain yang dapat

\footnotetext{
24 Azrul Azwar, Pengantar Administrasi Kesehatan, Binarupa Aksara, Jakarta, 1996, hal 17.

25 Andi Suswono, Makna Pelayanan Kesehatan dalam Era BPJS Kesehatan, artikel dalam Harian Republika tanggal terbitan 12 Januari 2016, hal 5.
} 
dipakai untuk memahami makna pelayanan kesehatan yaitu "upaya kesehatan". ${ }^{26}$

Peraturan Menteri Kesehatan Nomor 9 Tahun 2014 tentang Klinik. Pasal 1 angka 1 Permenkes Nomor 9 Tahun 2014 tentang Klinik, menyatakan bahwa Klinik adalah fasilitas pelayanan kesehatan yang menyelenggarakan pelayanan kesehatan perorangan yang menyediakan pelayanan medis dasar dan/atau spesialistik. Permenkes Nomor 9 Tahun 2014 tentang Klinik, Pasal 2 menentukan mengenai jenis klinik, yaitu klinik pratama dan klinik utama dan yang membedakannya adalah jika klinik pratama hanya menyelenggarakan pelayanan medik dasar, sedangkan klinik utama menyelenggarakan pelayanan spesialistik atau pelayanan medik dasar dan spesialistik.

Analisis, bahwa pelayanan medik dasar adalah pelayanan medik terhadap individu atau keluarga dalam masyarakat yang dilaksanakan oleh tenaga kesehatan maksimal dokter umum atau dokter gigi. Pelayanan medik spesialis adalah pelayanan medik terhadap individu atau keluarga dalam masyarakat yang dilaksanakan oleh dokter spesialis atau dokter gigi spesialis atau kelompok dokter spesialis. Termasuk keberadaan klinik pratama di Kabupaten Cilacap, memberikan pelayanan medik dasar berupa rawap inap dan rawat jalan. Klinik pratama rawat Inap khususnya di Kabupaten Cilacap, dapat dikategorikan sebagai pelayanan medik dasar. Meskipun demikian, dalam Peraturan Menteri Nomor 9 Tahun 2014 tentang Klinik tidak disebutkan tentang persyaratan tentang pelayanan medik dasar lain. Persyaratan tentang klinik pratama rawat inap

26 Ibid. diatur dalam Peraturan Menteri Kesehatan Republik Indonesia Nomor 9 Tahun 2014 tentang Klinik.

Pelayanan kesehatan tingkat pertama adalah pelayanan kesehatan yang diberikan oleh fasilitas pelayanan kesehatan dasar. Pelayanan kesehatan tingkat kedua adalah pelayanan kesehatan yang diberikan oleh fasilitas pelayanan kesehatan spesialistik. Pelayanan kesehatan tingkat ketiga adalah pelayanan kesehatan yang diberikan oleh fasilitas pelayanan kesehatan sub spesialistik.

Terkait dengan efektivitas pembinaan dan pengawasan tenaga medis terhadap operasional klinik berdasarkan Peraturan Menteri Kesehatan Nomor 9 Tahun 2014 di Kabupaten Cilacap, maka dari data yang penulis peroleh mengenai klinik pratama di Kabupaten Cilacap, bahwa klinik pratama rawat Inap di Kabupaten Cilacap berkembang cukup pesat. Pada tahun 2012 telah dikeluarkan izin operasional klinik pratama rawat inap sebanyak 23 (dua puluh tiga) klinik. Berkembangnya klinik tersebut terkait dengan upaya peningkatan pelayanan kesehatan kepada masyarakat. Data tahun 2014 didapatkan sebanyak 40 (empat puluh ) Klinik Pratama Rawat Inap, dan sampai dengan akhir bulan Desember 2015 tercatat ada 49 (empat puluh sembilan) Klinik Pratama Rawat Inap yang berizin dan beroperasional di Kabupaten Cilacap. ${ }^{27}$

Bahwa dinas kesehatan Kabupaten Cilacap telah melakukan pembinaan dan pengawasan yaitu berupa pendataan jumlah terhadap operasional klinik serta jumlah tenaga medis baik milik Pemerintah Daerah atau pun

27 Dinas Kesehatan Kabupaten Cilacap Tahun 2012 2015. 
milik swasta. Dalam penyelenggaraan usaha klinik Pratama Rawat Inap, para pesertanya akan mengadakan kerja sama dan dengan adanya kerja sama tersebut akan melahirkan konsekuensi yuridis, terutama mengenai tanggung jawab usaha klinik Pratama Rawat Inap tersebut. Dengan terbitnya Peraturan Menteri Kesehatan Nomor 9 Tahun 2014 tentang Klinik, dalam perkembangannya terkait dengan peningkatan upaya pelayanan kesehatan kepada masyarakat.

Masalah efektivitas pembinaan dan pengawasan tenaga medis terhadap operasional klinik berdasarkan Peraturan Menteri Kesehatan Nomor 9 Tahun 2014 di Kabupaten Cilacap, pembinaan dan pengawasan yang sudah dilakukan oleh dinas kesehatan dilakukan secara berkala. Pembinaan dimaksudkan agar Klinik Pratama Rawat Inap dalam penyelenggaraan pelayanan kesehatan sesuai ketentuan peraturan perundangundangan dan pengawasan dilakukan terkait dengan S.O.P yang ditetapkan sehingga tak terjadi masalah hukum dikemudian hari. ${ }^{28}$

Pembinaan dan pengawasan terkait dengan tenaga medis yang dilakukan oleh dinas kesehatan Kabupaten Cilacap terhadap klinik pratama rawat inap menemukan ada klinik pratama rawat inap yang belum ada apoteker sebagai penanggung jawab ruang farmasi (pengelola kefarmasian) pada klinik pratama rawat inap jelas melanggar ketentuan yang diatur dalam Pasal 21 Peraturan Menteri Kesehatan Nomor 9 Tahun 2014 tentang Klinik.

$28 \quad$ Hasil wawancara dengan dr. Marwoto, M.Si (Kepala Dinas Kesehatan Kabupaten Cilacap), pada tanggal 22 Februari 2016
SOP pembinaan dan pengawasan di klinik pratama rawat inap terkait tenaga medis di Kabupaten Cilacap, sebenarnya sudah berjalan dengan standar pelayanan kesehatan dan peraturan perundang-undangan khususnya Peraturan Menteri Nomor 9 Tahun 2014 tentang Klinik, namun ada juga SDM yang tak memenuhi, misalnya seorang dokter yang baru lulus pendidikan dokter begitu kerja terus ditempatkan di klinik pratama yang merupakan pelayanan kesehatan dasar, sehingga perlu diadakan penyuluhan dan pembinaan terlebih dahulu dari Dinkes Kabupaten Cilacap. ${ }^{29}$

Pembinaan dan pengawasan berdasarkan peraturan perundang-undangan terhadap tenaga medis pada klinik pratama yang menyelenggarakan pelayanan kesehatan rawap inap di Kabupaten Cilacap, pembinaan dilakukan berupa penyuluhan 3 (tiga) bulan sekali terutama mengenai S.O.P serta sosialisasi peraturan perundang-undangan yang terkait oleh dinas kesehatan Kabupaten Cilacap. Sedangkan pengawasan terhadap klinik pratama yang menyelenggarakan rawap inap di Kabupaten Cilacap berupa pendataan secara berkala baik berupa terhadap tenaga medis (dokter), perawat dan sarana prasarana (sanpras) di klinik tersebut.

Pembinaan dan pengawasan tenga
medis pada klinik pratama yang menyelenggarakan rawap inap, yang dilakukan dinas kesehatan Kabupaten Cilacap dalam bentuk pembinaan berupa penyuluhan yang tertuang dalam Berita Acara Penyuluhan yang dilakukan 3 (tiga) bulan sekali dan juga

Hasil wawancara dengan Mila Wijayanti, S.Kep Ness, M.MR (Staff Dinas Kesehatan Kabupaten Cilacap), pada tanggal 23 Februari 2016. 
dilakukan evaluasi secara menyeluruh baik fasilitas yang menunjang, peralatan medis, bentuk pelayanan dasar serta S.O.P klinik pratama. Pada kenyataannya, bahwa setelah klinik pratama yang menyelenggarakan rawap inap mendapatkan perizinan untuk operasional dari dinas kesehatan Kabupaten Cilacap, klinik tersebut dalam memberikan pelayanan kesehatan kepada masyarakat tidak sesuai dengan SOP yang mengacu pada peraturan perundang-undangan, hanya dilakukan berdasarkan pengetahuan secara umum yang dimiliki tenaga medis.

Adanya pelanggaran peraturan perundang-undangan yang dilakukan klinik pratama yang menyelenggarakan rawap inap di Kabupaten Cilacap, bahwa Bupati sesuai dengan kewenangannya telah mendelegasikan kepada kepala dinas kesehatan yang tertuang dalam Peraturan Daerah (Perda) Nomor 18 Tahun 2014 tentang Pelayanan Perizinan dan Non Perizinan Bidang Kesehatan Kabupaten Cilacap. Dalam hal ini, dinas kesehatan Kabupaten Cilacap telah melakukan tindakan administratif terhadap klinik pratama yang melanggar peraturan perundang-undangan dalam bentuk berupa teguran secara lisan, teguran secara tertulis serta pencabutan izin operasional klinik pratama.

\section{Faktor-faktor yang menghambat pembinaan} dan pengawasan Klinik Pratama Rawat Inap di Kabupaten Cilacap

Efektivitas pembinaan dan pengawasan tenaga medis terhadap operasional klinik berdasarkan Peraturan Menteri Kesehatan Nomor 9 Tahun 2014 tentang Klinik, di
Kabupaten Cilacap tentunya adanya faktorfaktor penghambat pelaksanaan Peraturan Menteri Kesehatan tersebut, antara lain dapat diketahui melalui hasil wawancara dengan beberapa narasumber antara lain :

dokter Marwoto, M.Si (Kepala Dinas

Kesehatan Kabupaten Cilacap), yang memberikan pendapatnya bahwa sebenarnya di setiap kabupaten/kota, termasuk di Dinas Kesehatan Kabupaten Cilacap belumlah siap mengenai implementasi Permenkes tersebut dikarenakan kurangnya sarana dan prasarana, namun khususnya Dinas Kesehatan Kabupaten Cilacap berusaha semaksimal mungkin menjalankan Permenkes tersebut. Faktor hukumnya juga mempengaruhi dalam pelaksanaan pembinaan dan pengawasan Klinik Pratama Rawat Inap, misalnya belum adanya peraturan pelaksana Permenkes tersebut. ${ }^{30}$

Slamet Budiarto, S.E., M.M (Kepala Bidang Pelayanan Kesehatan Dinas Kesehatan Kabupaten Cilacap), yang memberikan pendapatnya, yaitu : Adanya pembinaan dan pengawasan Klinik Pratama oleh Dinas Kesehatan Kabupaten Cilacap dalam rangka menindaklanjuti Permenkes Nomor 9 Tahun 2014 tentang Klinik, diperoleh data tentang pelayanan yang tidak sesuai standar, baik standar ketenagaan (dokter dan perawat). Karena dilapangan banyak terdapat klinik-klinik yang tenaga kesehatannya misalnya jumlah dokter seharusnya 2 orang, tetapi ada klinik pratama hanya ada 1 (satu) dokter. ${ }^{31}$

30 Hasil wawancara dengan dr. Marwoto, M.Si (Kepala Dinas Kesehatan Kabupaten Cilacap), pada tanggal 22 Februari 2016.

31 Hasil wawancara dengan Slamet Budiarto, S.E., M.M. (Kepala Bidang Pelayanan Kesehatan DinasKesehatan Kabupaten Cilacap), pada tanggal 22 Februari 2016. 
Pelaksana program Bidang Pelayanan Kesehatan Dinas Kesehatan Kabupaten Cilacap, Mila Wijayanti, S.Kep Ness, M.MR, yang menguraikan pendapatnya, bahwa pembinaan dan pengawasan klinik pratama di Kabupaten Cilacap yang menyelenggarakan rawap inap, dilihat dari sarana dan prasarana (sanpras) masih ada klinik pratama yang belum memiliki laboratarium, padahal dalam Permenkes Nomor 9 Tahun 2014 tentang Klinik, mengatur hal tersebut tertuang dalam Pasal 7 ayat (2), bahwa klinik pratama rawat inap harus memiliki antara lain : ruang rawat inap yang memenuhi persyaratan, ruang farmasi, ruang laboratorium dan ruang dapur. ${ }^{32}$

Erna Kartika Rahaju, S. Far (Staff Dinas Kesehatan Kabupaten Cilacap Bagian Farmasi). Narasumber memberikan pendapatnya, bahwa adanya faktor penghambat dalam pembinaan dan pengawasan klinik pratama di Kabupaten Cilacap yang menyelenggarakan rawap inap terutama tenaga medis belum semuanya memahami pembinaan berupa penyuluhan pelayanan kesehatan dari dinas kesehatan dan pengawasan dalam SOP agar tak terjadi sengketa hukum dengan pasien. Permenkes Nomor 9 Tahun 2014 tentang Klinik, masyarakat/pasien tak mengetahui adanya permenkes tersebut. $^{33}$

Selanjutnya dokter Siti Solihah, M.MR (Penanggungjawab Klinik Aisyah Kabupaten Cilacap). Narasumber memberikan pendapatnya, bahwa faktor penghambat dalam

\footnotetext{
32 Hasil wawancara dengan Mila Wijayanti, S.Kep Ness, M.MR (Pelaksana program Bidang Pelayanan Kesehatan Dinas Kesehatan Kabupaten Cilacap), pada tanggal 23 Februari 2016.

Hasil wawancara dengan Erna Kartika Rahaju, S. Far (Staff Dinas Kesehatan Kabupaten Cilacap Bagian Farmasi), pada tanggal 24 Februari 2016.
}

pembinaan dan pengawasan klinik pratama di Kabupaten Cilacap, salah satunya bahwa kurangnya kinerja klinik dalam memberikan pelayanan kesehatan masyarakat perlu mendapatkan perhatian yang lebih serius terutama yang berkaitan dengan SDM (sumber daya manusia) yang bekerja pada klinik pratama, karena tenaga medis pada klinik pratama di Kabupaten Cilacap terbatas. ${ }^{34}$

dokter Lini Nuraeni (Penanggungjawab Klinik Gelis Bergas Kabupaten Cilacap. Menguraikan pendapatnya tentang tenaga medis di klinik pratama, bahwa faktor penghambat pelaksanaan Peraturan Menteri Kesehatan Nomor 9 Tahun 2014 tentang Klinik, di Kabupaten Cilacap banyak masyarakat tidak mengetahui Permenkes tersebut, sehingga masyarakat dalam menyembuhkan penyakit yang diderita cenderung berobat ke pengobatan alternatif. ${ }^{35}$

Analisis, terkait dengan faktor-faktor tersebut di atas, pembinaan dan pengawasan terhadap tenaga medis pada klinik pratama di Kabupaten Cilacap yang menyelenggarakan pelayanan kesehatan rawap inap, bahwa setelah klinik beroperasional diantara para tenaga medis (dokter) meninggalkan klinik tersebut dan mencari pekerjaan di tempat lain (Rumah Sakit atau klinik swasta yang lain), seharusnya tenaga medis (dokter) dalam klinik pratama adalah 2 (dua) dokter, namun pada kenyataannya banyak ditemukan klinik pratama hanya ada 1 (satu) dokter, penyebabnya antara

\footnotetext{
$34 \quad$ Hasil wawancara dengan dokter Siti Solihah, M.MR (Penanggungjawab Klinik Aisyah Kabupaten Cilacap), pada tanggal 25 Februari 2016.

35 Hasil wawancara dengan dokter Lini Nuraeni (Penanggungjawab Klinik Gelis Bergas Kabupaten Cilacap), pada tanggal 25 Februari 2016.
} 
lain kesejahteraan/honor yang diterima tenaga medis tidak sesuai dengan UMR dikarenakan pemasukan pembiayaan dari pasien yang diterima klinik tersebut tidak mampu untuk biaya operasional klinik, sarana dan prasarana klinik yang kurang menunjang, ketidakcocokan antara pemilik klinik tenaga medis (dokter), dan jarak tempuh dokter ke klinik terlalu jauh.

Efektifitas hukum dalam tindakan atau realita hukum dapat diketahui apabila seseorang menyatakan bahwa suatu kaidah hukum berhasil atau gagal mencapai tujuannya, maka hal itu biasanya diketahui apakah pengaruhnya berhasil mengatur sikap tindak atau perilaku tertentu sehingga sesuai dengan tujuannya. Salah satu upaya yang biasanya dilakukan agar supaya masyarakat mematuhi kaidah hukum adalah dengan mencantumkan sanksisanksinya. ${ }^{36}$

Soerjono Soekanto, menyatakan bahwa masalah penegakan hukum sebenarnya terletak pada faktor-faktor yang mungkin mempengaruhinya. ${ }^{37}$ Faktor faktor tersebut adalah sebagai berikut:

\section{Faktor Hukum/Undang-Undang}

Undang-undang merupakan peraturan ter-tulis yang berlaku umum dan dibuat oleh penguasa pusat maupun daerah yang sah. Undang-undang merupakan pengejawantahan nilai-nilai yang disepakati pemerintah.

\section{Faktor Penegak Hukum}

Ruang lingkup suatu penegakan hukum adalah sangat luas, karena mencakup

\footnotetext{
36 Himawan Sulistiono, Hukum Sebagai Kaidah dalam Masyarakat, artikel internet http//www.kompas.com, diakses pada tanggal 12 Oktober 2015

37 Soerjono Soekanto, Faktor-Faktor Yang Mempengaruhi Penegakan Hukum, Rajawali Pers, Jakarta, 2011, hal 8.
}

mereka yang secara langsung maupun tidak langsung berkecimpung dalam penegakan hukum. ${ }^{38}$ Untuk membatasi hal yang luas tersebut maka mengartikan penegakan hukum skala subjektif penegakan hukum haruslah tertentu yaitu polisi, jaksa, hakim, dan pengacara. Faktor penegak hukum memegang peran dominan. Beberapa permasalahan yang dihadapi penegak hukum antara lain:

a. Tingkat aspirasi yang belum tinggi.

b. Kegairahan yang sangat terbatas untuk memikirkan masa depan, sehingga sulit sekali untuk membuat suatu proyeksi.

c. Belum adanya kemampuan menunda pemuasan suatu kebutuhan tertentu, terutama kebutuhan materil.

d. Kurangnya daya inovatif yang sebenarnya merupakan pasangan konservatisme.

e. Keterbatasan kemampuan untuk menempatkan diri dalam peranan pihak lain dengan siapa dia berinteraksi. $^{39}$

Tingkat aspirasi yang belum tinggi dari masyarakat terutama yang berkaitan dengan implementasi suatu peraturan perundang-undangan dalam bidang kesehatan yang msyarakat tidak mengetahuinya. Kegairahan yang sangat terbatas untuk memikirkan masa depan, sehingga sulit sekali untuk membuat suatu proyeksi, ini berkaitan dengan rendahnya sumber daya manusia termasuk pendidikan

Ibid., hal 19.

Ibid., hal 34-35. 
yang ditempuh untuk menerima aturanaturan yang diterapkan oleh pemerintah sehingga terjadi kesulitan dalam pemahaman aturan yang berlaku. Belum adanya kemampuan menunda pemuasan suatu kebutuhan tertentu, terutama kebutuhan materil bahwa setiap orang mempunyai kebutuhan yang berbeda-beda sehingga terjadi kesenjangan sosial di masyarakat. Kurangnya daya inovatif yang sebenarnya merupakan pasangan konservatisme, ini juga berkaitan dengan semangat yang ada di dalam masyarakat untuk memahami suatu kebutuhan terutama dalam hal kesehatan berupa Jaminan Kesehatan dari pemerintah. Keterbatasan kemampuan untuk menempatkan diri dalam peranan pihak lain dengan siapa dia berinteraksi, bahwa kurangnya peran dari pemangku kepentingan umum dan keterbatasan keterbatasan dari sarana dan prasarana yang mendukung terutama layanan kesehatan.

3. Faktor Sarana atau Fasilitas

Tanpa adanya fasilitas tertentu, maka tidak mungkin penegakan hukum akan berlangsung dengan lancar. Sarana atau fasilitas tersebut antara lain mencakup tenaga manusia yang berpendidikan dan terampil, organisasi yang baik, peralatan yang memadai, keuangan yang cukup dan lainnya. ${ }^{40}$

4. Faktor Masyarakat

Penegakan hukum berasal dari masyarakat dan bertujuan untuk mencapai kedamaian di dalam masyarakat. Oleh

\footnotetext{
$40 \quad$ Ibid., hal 37.
}

karena itu dipandang dari sudut tertentu, maka masyarakat dapat mempengaruhi penegakan hukum tersebut. Terdapat beberapa faktor masyarakat yang menimbulkan hambatan bagi penegakan hukum anatara lain:

a. Tidak mengetahui atau tidak menyadari, apabila hak-hak mereka dilanggar atau terganggu.

b. Tidak mengetahui akan adanya upayaupaya hukum untuk melindungi kepentingan-kepentingannya.

c. Tidak berdaya untuk memanfaatkan upaya-upaya hukum karena faktorfaktor keuangan, psikis, sosial atau politik.

d. Tidak mempunyai pengalaman menjadi anggota organisasi yang memperjuangkan kepentingankepentingannya.

e. Mempunyai pengalaman-pengalaman kurang baik di dalam proses interaksi dengan pelbagai unsur kalangan hukum formal. ${ }^{41}$

\section{Faktor Kebudayaan}

Kebudayaan pada dasarnya mencakup nilai-nilai yang mendasari hukum yang berlaku, nilai-nilai yang merupakan konsepsi abstrak mengenai apa yang dianggap baik sehingga dianut dan apa yang dianggap buruk sehingga dihindari. Nilai-nilai tersebut lazimnya merupakan pasangan nilai-nilai yang mencerminkan dua keadaan ekstrim yang harus diserasikan. ${ }^{42}$ 
Terkait dengan efektivitas pembinaan dan pengawasan tenaga medis terhadap operasional klinik berdasarkan Peraturan Menteri Kesehatan Nomor 9 Tahun 2014 di Kabupaten Cilacap, tentunya dalam pelaksanaannya ada faktor-faktor yang menghambat, antara lain:

\section{Faktor Hukum/Undang-Undang}

Dari hasil penelitian, sebenarnya di setiap kabupaten/kota, termasuk di Dinas Kesehatan Kabupaten Cilacap belumlah siap mengenai implementasi Permen tersebut dikarenakan kurangnya sarana dan prasarana, namun khususnya Dinas Kesehatan Kabupaten Cilacap berusaha semaksimal mungkin menjalankan Permenkes tersebut. Faktor hukumnya juga mempengaruhi dalam pelaksanaan pembinaan dan pengawasan Klinik Pratama Rawat Inap, misalnya belum adanya peraturan pelaksana Peraturan Menteri Nomor 9 Tahun 2014 tentang Klinik. ${ }^{43}$

\section{Faktor Penegak Hukum}

$$
\text { Dalam penelitian ini, penulis }
$$
mengidentifikasi aparat penegak hukum yaitu tenaga medis. Adanya pembinaan dan pengawasan Klinik Pratama oleh Dinas Kesehatan Kabupaten Cilacap dalam rangka menindaklanjuti Permenkes Nomor 9 Tahun 2014 tentang Klinik, diperoleh data tentang pelayanan yang tidak sesuai standar, baik standar ketenagaan (dokter dan perawat). Karena dilapangan banyak terdapat klinik-klinik

43 Hasil wawancara dengan dr. Marwoto, M.Si (Kepala Dinas Kesehatan Kabupaten Cilacap), pada tanggal 22 Februari 2016. yang tenaga kesehatannya misalnya jumlah dokter seharusnya 2 orang, tetapi ada klinik pratama hanya ada 1 (satu) dokter. $^{44}$

3. Faktor Sarana atau Fasilitas

Dari hasil penelitian, pembinaan dan pengawasan klinik pratama di Kabupaten Cilacap yang menyelenggarakan rawap inap, dilihat dari sarana dan prasarana (sanpras) masih ada klinik pratama yang belum memiliki laboratarium, padahal dalam Permenkes Nomor 9 Tahun 2014 tentang Klinik, mengatur hal tersebut tertuang dalam Pasal 7 ayat (2), bahwa klinik pratama rawat inap harus memiliki antara lain : ruang rawat inap yang memenuhi persyaratan, ruang farmasi, ruang laboratorium dan ruang dapur. ${ }^{45}$

4. Faktor Masyarakat

Dalam penelitian ini, faktor penghambat pelaksanaan Peraturan Menteri Kesehatan Nomor 9 Tahun 2014 tentang Klinik, di Kabupaten Cilacap banyak masyarakat tidak mengetahui Peraturan Menteri Kesehatan Nomor 9 Tahun 2014 tentang Klinik tersebut, sehingga masyarakat dalam menyembuhkan penyakit yang diderita cenderung berobat ke pengobatan alternatif. Efektivitas pembinaan dan pengawasan tenaga medis terhadap

44 Hasil wawancara dengan Slamet Budiarto, S.E., M.M. (Kepala Bidang Pelayanan Kesehatan Dinas Kesehatan Kabupaten Cilacap), pada tanggal 22 Februari 2016.

45 Hasil wawancara dengan Mila Wijayanti, S.Kep Ness, M.MR (Pelaksana program Bidang Pelayanan Kesehatan Dinas Kesehatan Kabupaten Cilacap), pada tanggal 23 Februari 2016. 
operasional klinik berdasarkan Peraturan Menteri Kesehatan Nomor 9 Tahun 2014 di Kabupaten Cilacap, adanya faktor penghambat terhadap pembinaan dan pengawasan tenaga medis persoalan yang tersendiri, terutama S.O.P yang ditetapkan sehingga tidak terjadi masalah hukum dikemudian hari.

5. Faktor Kebudayaan

Dalam penelitian ini, adanya faktor penghambat dalam pembinaan dan pengawasan klinik pratama di Kabupaten Cilacap yang menyelenggarakan rawap inap terutama tenaga medis belum semuanya memahami pembinaan berupa penyuluhan pelayanan kesehatan dari dinas kesehatan dan pengawasan dalam SOP agar tak terjadi sengketa hukum dengan pasien. Permenkes Nomor 9 Tahun 2014 tentang Klinik, masyarakat/pasien tak mengetahui adanya permenkes tersebut. ${ }^{46}$ Faktor penghambat dalam pembinaan dan pengawasan klinik pratama di Kabupaten Cilacap, salah satunya bahwa kurangnya kinerja klinik dalam memberikan pelayanan kesehatan masyarakat perlu mendapatkan perhatian yang lebih serius terutama yang berkaitan dengan SDM (sumber daya manusia) yang bekerja pada klinik pratama, karena tenaga medis pada klinik pratama di Kabupaten Cilacap terbatas. $^{47}$

\footnotetext{
${ }^{46}$ Hasil wawancara dengan Erna Kartika Rahaju, S Farm.,Apt. (Staff Dinas Kesehatan Kabupaten Cilacap Bagian Farmasi), pada tanggal 24 Februari 2016.

47 Hasil wawancara dengan dokter Siti Solihah, M.MR (Penanggungjawab Klinik Aisyah Kabupaten Cilacap), pada tanggal 25 Februari 2016.
}

Bahwa setelah mendapatkan perizinan dari dinas kesehatan Kabupaten Cilacap, klinik pratama yang menyelenggarakan pelayanan kesehatan rawap inap hanya mempertimbangkan aspek keuntungan semata bukan pelayanan secara maksimal kepada pasien. Sehingga keberadaan tenaga medis di klinik pratama kadang tidak dipertimbangkan lagi, klinik dikelola hanya oleh 1 (satu) tenaga medis atau bahkan hanya para tenaga medis (perawat).

\section{PENUTUP}

\section{Simpulan}

Efektivitas pembinaan dan pengawasan tenaga medis terhadap operasional klinik berdasarkan Peraturan Menteri Kesehatan Nomor 9 Tahun 2014 di Kabupaten Cilacap bahwa, pembinaan dan pengawasan tenga medis pada klinik pratama yang menyelenggarakan rawap inap, dilakukan dinas kesehatan Kabupaten Cilacap dalam bentuk pembinaan berupa penyuluhan yang tertuang dalam Berita Acara Penyuluhan yang dilakukan 3 (tiga) bulan sekali serta evaluasi secara menyeluruh baik fasilitas yang menunjang, peralatan medis, bentuk pelayanan dasar serta S.O.P klinik pratama. Pada kenyataannya, Peraturan Menteri Kesehatan Nomor 9 Tahun 2009 tentang Klinik belum efektif, karena setelah klinik pratama yang menyelenggarakan rawap inap mendapatkan perizinan untuk operasional dari dinas kesehatan Kabupaten Cilacap, klinik tersebut dalam memberikan pelayanan kesehatan kepada masyarakat tidak 
sesuai dengan SOP yang mengacu pada peraturan perundang-undangan, hanya dilakukan berdasarkan pengetahuan secara umum yang dimiliki tenaga medis.

Dinas kesehatan Kabupaten Cilacap telah melakukan tindakan administratif terhadap klinik pratama yang melanggar peraturan perundang-undangan dalam bentuk berupa teguran secara lisan, teguran secara tertulis serta pencabutan izin operasional klinik pratama. Adanya Faktor penghambat dalam pembinaan dan pengawasan tenaga medis berdasarkan Peraturan Menteri Kesehatan Nomor 9 Tahun 2014 tentang Klinik di Kabupaten Cilacap, meliputi : 1) Faktor hukumnya, 2) Faktor penegak hukum, 3) Faktor sarana dan prasarana, 4) Faktor masyarakat, dan 5) Faktor kebudayaan.

\section{Saran}

Berdasarkan kesimpulan di atas, dapat disarankan hal-hal sebagai berikut:

1. Pelaksanaan Peraturan Menteri Kesehatan Nomor 9 Tahun 2014 tentang Klinik di Kabupaten Cilacap belum efektif, sehingga pemerintah Kabupaten Cilacap khususnya dinas kesehatan perlu melakukan sosialisasi Permenkes tersebut agar pelayanan kesehatan berjalan lancar.

2. Faktor penghambat dalam pembinaan dan pengawasan tenaga medis berdasarkan Peraturan Menteri Kesehatan Nomor 9 Tahun 2014 tentang Klinik di Kabupaten Cilacap, hendaknya dinas kesehatan memberikan Juklak dan para pemilik klinik pratama untuk melakukan koordinasi dan kerjasama sehingga faktor penghambat

\begin{abstract}
Permenkes tersebut dapat ditanggulangi seminimal mungkin. Penelitian ini belum sempurna, sehingga perlu dilakukan penelitian lebih lanjut oleh peneliti berikutnya.
\end{abstract}

\section{DAFTAR PUSTAKA}

\section{Buku}

Amiruddin dan Zainal Ashikin, Pengantar Metode Penelitian Hukum, PT. Raja Grafindo Persada, Jakarta, 2004.

Azwar, Azrul, Pengantar Administrasi Kesehatan, Binarupa Aksara, Jakarta, 1996.

Hanintijo Sumitro, Ronny, Metodologi Penelitian Hukum, Ghalia Indonesia, Jakarta, 1988.

Kadir Muhammad, Abdul, Metode Penelitian Hukum, PT. Raja Grafindo, Jakarta, 2004.

Soekanto, Soerjono, Faktor-Faktor Yang Mempengaruhi Penegakan Hukum, Rajawali Pers, Jakarta, 2011.

Sunggono, Bambang, Metode Penelitian Hukum, PT Raja Grafindo Persada, Jakarta, 2006.

Sulistiono, Himawan, Hukum Sebagai Kaidah dalam Masyarakat, artikel internet http//www.kompas.com, diakses pada tanggal 12 Oktober 2015.

Suswono, Andi, Makna Pelayanan Kesehatan dalam Era BPJ S Kesehatan, artikel dalam Harian Republika tanggal terbitan 12 Januari 2016.

Sony Wijaya, Keberadaan Klinik dan Pelayanan Kesehatan oleh Dokter, http://www.klinikonline.blogspot.com, diakses pada tanggal 28 September 2015.

\section{Perundang-Undangan}

Peraturan Menteri Kesehatan Nomor 9 Tahun 2014 tentang Klinik.

Undang-undang Nomor 29 Tahun 2004 tentang Praktik Kedokteran.

Undang-undang Nomor 36 Tahun 2009 tentang Kesehatan. 